\title{
Review note
}

\section{Extending the Cosmopolitical Right to Non-Humans}

\author{
Helen Verran
}

\begin{abstract}
This short essay is a review of Bruno Latour's An Inquiry into Modes of Existence: An Anthropology of the Moderns (Harvard University Press, 2013) and a commentary on the wider move that accompanies the book.
\end{abstract}

Should readers of Valuation Studies bother themselves with the latest intellectual fad emerging from the Left Bank in Paris? I will suggest there is at least one good reason to do so. An Inquiry into Modes of Existence, the latest modernizing intervention to emerge from Paris' 6th and 7th arrondissements, a hotspot of modernizing activity in the past, has valuation in its sights. The very place that gave us the modern valuation regime of 'rational metrication' is at this very moment planning to set a few depth charges; planning how to blow things apart in a significant section of the world of valuation, in order to start again. This time the valuation regimes in question must be designed to avoid the epistemological mistake of believing and acting as if valuations associated with economization can be made referential in the way say cartographic valuations can (with great difficulty) be made and maintained as referential. Before I consider this foreshadowed intervention however, I attempt to introduce An Inquiry into Modes of Existence-a sprawling endeavour of an interactive website understood as a multimedia platform, an impressive social marketing campaign, and a book (a fat advertising pamphlet?). ${ }^{1}$ As you might gather from my title, I set Latour's injunction that we should re-

Helen Verran, School of Historical and Philosophical Sciences, University of Melbourne,Australia,hrv@unimelb.edu.au

(C) 2014 Helen Verran

LiU Electronic Press, DOI 10.3384/vs.2001-5992.142165

http://valuationstudies.liu.se 
institute modernity as cognizant of its core values (which is why valuations associated with economization need to be blown apart), alongside a proposal on modernity promulgated from Prussia's Königsberg in 1795, in the form of Kant's cosmopolitical right. I will develop that analogy in concluding my review.

It is a mistake to think of An Inquiry into Modes of Existence as just Latour's latest and most fantastic intervention. It is that nevertheless, a continuation of the trajectory of Latour's idiosyncratic attempt to characterize modernity and thus diagnose the roots of the planet's ecological crisis. This might be seen as beginning with the polemic We Have Never Been Modern (Latour 1993), continued through The Politics of Nature (Latour 2004). However, since in common with Inquiry into Modes of Existence, these books are characterized by Latour's resolute refusal of modernity's reductionism, it is useful to understand "Irreductions" (Latour 1988) as the source. Seen from this starting point the trajectory incorporates Latour's inveighing against the 'iconoclashes' of modern critique (the upshot of competing reductions vying for dominance) in Iconoclash (Latour and Weibel 2002), and The Modern Cult of the Factish Gods (Latour 2010). Latour has stayed loyal to the brand of metaphysics he began with. But An Inquiry into Modes of Existence is not only a book: the interactive website (www.modesofexistence.org), which a cynic might claim is just a means of crowd sourcing content, and a travelling roadshow with Bruno as its star, are just as integral to the project. The book has no index, but the multimedia platform (the "extended book"), which encourages contributions from fellow "anthropologists of modernity," incorporates (a perhaps overwhelming, and often rather slow) searchability. I found that neither of these elements were satisfying to use on their own, but that they work together well. Together the elements of An Inquiry into Modes of Existence exemplify two important modes of existence-the networking mode of existence, and the position-taking mode (which here is called the prepositional mode), and also offer some sort of culmination of Latour's analytic journey.

So how to characterize this Inquiry? Here's how Latour explains its purpose:

[Through this enquiry] I am exploring ... a series of contrasts to distinguish the values that [Modern] people are seeking to defend from the account that has been given of them throughout history, so as to attempt to establish these values, or better yet to install them, in institutions that might finally be designed for them. (Latour 2013, 7)

How is the "series of contrasts" presented? I read An Inquiry into Modes of Existence as a blue-print for a working a machine of the sort loved by semioticians; a machine that in its workings reveals "useful contrasts." In developing this machine the hope is to sensitise Moderns 
who engage with it to clashes of values that, over several hundred years, they have learned to simultaneously experience and not experience. It is hoped that through taking to this machine many Moderns will, perhaps for the first time, articulate their disconcertment at such clashes of values. Thus the website is an attempt to crowd source stories of disconcertment. The grand end-point of this cycle of reform will perhaps set about the task of re-establishing institutions, and begin the next cycle. This is an ambitious and long-term project.

The machine, which both seeks to sensitise Moderns to clashes of values, and to support the articulation of stories of disconcertment, takes some time getting into however; much to and fro-ing from the book to the website is needed. Like all good semiotic machines it's clunky and exaggerated. But then its ancestors were perhaps even more preposterous. I speculate that its parents are Donna Haraway's "Four Square Cyborg," and A.J. Greimas' "infamous semiotic square ... a clackety, structuralist meaning making machine." Here is how Haraway introduces her line of "artificial devices that generate meanings very noisily"-Haraway could be understood as foreshadowing the semiotic machine of the Inquiry:

To get through the artifactual to elsewhere, it ... help[s] to have a little travel machine that also functions as a map ... [, ] a structuralist engine put to amodern purposes ... [,] a view of the history of science as a culture that insists on the absence of beginnings, enlightenments, and endings: the world has always been in the middle of things in unruly and practical conversation, full of action and structured by a startling array of actants and of networking and unequal collectives ... [.] [This] amodern history will have a different geometry, not of progress, but of permanent and multi-patterned interaction through which lives and worlds get built, human and unhuman. (Haraway 1992, 304)

The trajectory of Latour's analytic journey, and a semiotic machine of the sort favoured by Haraway? All this probably seems quite distant from the interests of those studying modernity's valuation regimes. Let's take a closer look at how the machine of the Inquiry is currently working in the academy.

\section{Calculemus!}

Part of wonder of An Inquiry into Modes of Existence is its generosity in inviting (and funding) engagement. A series of workshops and lectures have been organized across 2013 and 2014 and, at the time I write, preparations are underway for a workshop that readers of Valuation Studies would do well to pay attention to: "Let's Calculate: Reinventing Accounting with Bruno Latour." 2 This is how the call for contributions starts:

Calculemus! (Let's Calculate!) Thus finishes Bruno Latour's last book . . . where he takes on accounting frontally and calls for its reinvention. Modern 
accounting, Latour argues, is indeed the cause of major evils, and therefore also the place where reform should start if one wants to close the modernist parenthesis and finally settle the debt of the West, the Whites, or yet again the Moderns with the rest of the world. This workshop aims at understanding, discussing and eventually furthering this new, radical critique of accounting.

It is not just the profession of accounting and its academic arm that is to be confronted here. To understand what is under attack one needs to grasp the term 'economization' as it is used in the Inquiry, following the approach of Latour's former colleague Michel Callon: "When one is dealing with economic matter, one has to be prepared to pile performatives on top of performatives, like tortoises in the fable, 'all the way down'!" (Latour 2013, 405). It comes down to devices of economization and the duplicitous masquerade they wage in presenting themselves as devices of referentiality when in actuality they are devices of control-devices of bad faith used with good will, when what we need, as any good contract lawyer will tell you, is devices of bad will, used in good faith.

"The [e]conomy fuses with organization to obtain idealized matter it uses inappropriately to shut down its calculations of interests and passions rather too quickly" (Latour 2013, 411). Thus the call: Calculemus! If Latour and his team have their way, the days of economy's/economics' duplicity are numbered. Recognizing that economics "produces measuring measures [methods of control] and not measured measures [assessments of extent]" (Latour 2013, 408), economic valuation will be changed forever. Of course this recognition will involve considerable re-organization; significant reinstitutionalization. Before that can be done, we need to collectivelyand this time wittingly-invent a few devices that will, in bringing publics into existence, initiate, maintain, regulate, and publicize flows of organization proceeding in the opposite direction. ${ }^{3}$ You can see why I think readers of Valuation Studies need to collectively prick up their ears.

\section{Extending the Right of Cosmopolitics to Non- Humans}

So why set the Inquiry alongside a proposal made by Kant foreshadowing a cosmopolitical right (for humans)? In 1795, writing at the cusp of a waning feudal Europe and the dawn of capitalist modes of production, Kant argued that international commerce was a historical condition of the cosmopolitical community because commerce was incompatible with war and the self-interest of states. Appalled by the vision of "perpetual war" as the seeming implacable consequence of Hobbes' account of modernity, Kant's vision of a cosmopolitical right asserted in the name of a common humanity, attempted to provide an ideal institutional framework for "perpetual 
peace" through regulating the anarchic behaviour of states (Kant 1999).

Latour's Inquiry comes to life in Europe at a time when the cosmopolitanism of the European Union begins to fade under the assaults of nationalism (again), when the might of corporations who dominate international trade far exceeds the strength of many nations, and when modernity has progressed so far that in the face of ecological crisis, now economization (in the form of financialization) of the very planetary stuff that feeds modernity and its capitalizations, seems an appropriate response. Appalled at the continuing blindness of moderns to the values that should have been institutionalized in Kant's times and places, but which because of an absurd collective bedazzlement by ideals were unrecognized, indeed unrecognizable, Latour and his team set out to act.

Not attracted to ideal institutions at all-that's what's caused the problems since they brought with them ideal epistemic practices-the Inquiry has cosmopolitics proceeding in the opposite direction, from the ground up so to speak, and this is how non-humans will get into the collective acting this time around, if the team have their way. But how are we to have a chance of knowing what we're doing as, collectively, we blindly feel around the elephant of modernity, with no agreement on what this phenomenon is? This is where the machine comes in. It both helps "read the surface of the elephant that is modernity," and helps connect groups and individuals feeling the bumps and crevices in various sites-Latour has started us off by identifying fifteen sites; fifteen modes of modern existence. But, in his opinion, turning around the direction of economization is the most urgent. This does seem to be something to which those of us with interests in the workings of valuation regimes need pay attention.

\section{Notes}

1. The book (Latour 2013) is accompanied by a project ("AIME" for "An Inquiry into Modes of Existence") hosted by Science Po in Paris, which counts on a team of collaborators and an internet platform available at: www.modesofexistence.org (accessed 25 March 2014).

2. "Let's Calculate: Reinventing Accounting with Bruno Latour?" AIME Workshop, Paris, 5 May 2014, organized by Martin Giraudeau and Vincent Lépinay. See: www.modesofexistence.org (accessed 25 March 2014).

3. Helpfully recognizing that examples are important in this task, one contributor to the "extended book" points out this is the direction that accounting/economic/organizational valuation proceeded in ancient Egypt, referring us to the paper by Mahmoud Ezzamel (2009). 


\section{References}

Ezzamel, Mahmoud.2009. "Order and Accounting as a Performative Ritual: Evidence from Ancient Egypt." Accounting, Organizations and Society, 34 (3-4): 348-380.

Haraway, Donna. 1992. "The Promises of Monsters: A Regenerative Politics for Inappropriate/d Others." In Cultural Studies, edited by Lawrence Grossberg, Cary Nelson, and Paula A. Treichler, 295-337. New York: Routledge.

Kant, Immanuel. 1999. "Perpetual Peace: A Philosophical Sketch." In Political Writings, edited by Hans Reiss, 98-99. Cambridge: Cambridge University Press.

Latour, Bruno. 1988. The Pasteurization of France. Cambridge, MA: Harvard University Press.

— 1993. We Have Never Been Modern. Cambridge, MA: Harvard University Press.

- 2004. The Politics of Nature: How to Bring the Sciences into Democracy. Cambridge, MA: Harvard University Press.

. 2010. On the Modern Cult of the Factish Gods. Durham, NC: Duke University Press.

- 2013. An Inquiry into Modes of Existence: An Anthropology of the Moderns. Cambridge, MA: Harvard University Press.

Latour, Bruno, and Peter Weibel, eds. 2002. Iconoclash: Beyond the Image Wars in Science, Religion and Art. Cambridge, MA: The MIT Press.

Helen Verran researches in anthropology, philosophy, and sociology of science and technology. She is reader (emeritus) in History and Philosophy of Science at the University of Melbourne where she taught for twenty five years, and adjunct professor at the Northern Institute, Charles Darwin University in Australia. The author of prize-winning Science and an African Logic (Chicago University Press 2001), Helen Verran studies, among other topics, how practitioners of disparate knowledge traditions produce numbers and work with them. 